\title{
O Direito Econômico e o Direito Empresarial
}

\author{
Peter Walter Ashton*
}

É propósito deste artigo analisar os princípios básicos que informam o Direito Econômico bem como o Direito Empresarial nele contido. Muitas faculdades de Direito rebatizaram o antigo Direito Comercial de Direito Empresarial, mudando e adaptando seus currículos, sem que tivesse havido uma informação mais detalhada a respeito das importantes diferenças que a nosso ver existem, ou melhor, passaram a existir entre o conteúdo do antigo Direito Comercial, influenciado pela teoria objetiva (atos de comércio) do Código Napoleônico de 1807 e o novo Direito Empresarial que é lecionado, não somente na graduação do curso de Direito, mas também na pós-graduação de Direito, geralmente sob o título Curso de Especialização de Direito Empresarial, pós-graduação lato sensu.

Antes de adentrarmos numa análise do Direito Econômico, que abrange o
Direito Empresarial, convém informar o leitor que ao fazer essa análise nós nos inclinamos a utilizar obras jurídicas de autores europeus, particularmente alemães, cujas análises nos pareceram especialmente claras, analíticas, sistemáticas e doutrinariamente muito bem embasadas. Essa nossa opção até surpreendeu a nós mesmos, pois nosso mestrado em Direito Empresarial (Sociedades por Ações, Mercado de Capitais e Mercado Financeiro, Associações em geral e Sociedades de Pessoas, além de instrumentos contratuais societários) foi cursado e obtido, com defesa de tese, nos Estados Unidos, portanto num sistema jurídico anglo-saxônico e não continental como o alemão. No entanto tudo o que nós estudamos, há quarenta e cinco anos atrás, por ocasião do nosso mestrado, era prática e exclusivamente case law com pouquíssima doutrina, predominando sempre a jurisprudência

\footnotetext{
* Professor titular aposentado, ex-diretor, docente do PPG de Direito da UFRGS.
} 
dos tribunais superiores americanos que tinha que ser exaustivamente estudada e interpretada. Não era adotado portanto um manual ou curso de Direito Econômico. Ainda em fins da década dos anos 80 o direito anglo-americano mantinha, doutrinariamente, um nítido distanciamento relativamente à discussão a respeito da natureza jurídica do Direito Econômico visto de um ponto-de-vista sistemático, posição completamente diferenciada relativamente ao direito continental europeu, particularmente o alemão. É esta razão pela qual nos decidimos de abordar a temática a partir dos escritos dos juristas alemães, já que didaticamente é relativamente mais fácil analisar a doutrina alemă a respeito do tema, do que adentrar, por exemplo, na sistemática do case law americano.

Outro motivo que nos levou a pesquisar o direito econômico alemão é a sua evolução, particularmente interessante, pois passou por vários estágios, como veremos mais adiante no texto, beirando no início do século 20 , um talvez catastrófico mergulho, no comunismo, com uma economia totalmente planejada e com exclusão da propriedade privada, para, a partir de 1949 , decolar com Ludwig Erhard para uma economia de mercado com responsabilidade social, situação que perdura até a atualidade.

Isto posto, passamos a eleger, entre os vários doutrinadores de Direito Econômico alemães, aquele que nos pareceu mais objetivo e mais indicado para o propósito deste artigo, que afinal de contas se destina, principalmente para ser lido por alunos da graduação e eventualmente da pós-graduação.

Não são muitos os doutrinadores alemães que se dedicaram ao tema do Direito Econômico. Dentre eles escolhemos Fritz Rittner que a nosso ver é o mais didático e menos abstruso na análise do tema que apresenta no seu Grande Manual de Ensino do Direito Econômico, $2^{a}$ ed., publicado pela Editora C.F. Muller de Heidelberg.

Desde já deixamos claro que apenas pretendemos levar ao conhecimento dos nossos alunos do passado, presente $\mathrm{e}$ futuro o que é o Direito Econômico, como no seu contexto se situa o Direito Empresarial, disciplina mais vasta e mais moderna do que o antigo Direito Comercial e já não mais tão privatística, mas profundamente influenciada pelo Direito do Estado, tudo isso pela simples razão que tudo que diz respeito à Economia de um país interessa muito de perto ao Estado pelos mais diversos motivos, como veremos mais adiante. Portanto, quando se estuda qualquer uma das disciplinas do Direito Empresarial, sempre deve se levar em conta, mesmo que isso pareça um incômodo, a presença do Estado.

Por termos optado pela leitura da obra de Rittner, é évidente que boa parte do que passaremos a expor é daquele autor, já que, declaradamente, passamos a absorver e reproduzir os pensamentos e as afirmativas, daquele doutrinador alemão. Por isso, não temos a pretensão de sermos originais, mas apenas a transmitir ao leitor, de forma resumida, entre outras, as lições do professor Rittner. 


\section{SURGIMENTO E EVOLUÇÃO DO DIREITO ECONÔMICO NA ALEMANHA}

Indagações a respeito de um "moderno Direito Econômico" iniciam na Alemanha no albor do século 20 . No entanto, até hoje, inexiste uma resposta aceita pela generalidade da doutrina. Daí, convém, primeiramente examinar a evolução histórica do direito econômico, para, somente, após, formular a pergunta jurídico-sistemática sobre a configuração do mesmo.

O sistema jurídico alemão que provinha do século 19 , desconhecia o Direito Econômico. Todo direito estava contido em duas grandes áreas: o Direito Privado e o Direito Público. Ambos os ramos tinham-se desenvolvido enormemente e produzido institutos que até hoje permanecem. No Direito Privado as grandes codificações fundamentadas no direito das pandectas, e no Direito Público, partes significativas do Direito Constitucional e Administrativo já pertencentes a um Estado de Direito. A vida econômica, no século 19, mudara extraordinariamente, no entanto, estas modificações não se refletiram na sistemática jurídica. Ocorre que o "labutar na economia" (Das Wirtschaften) era prerrogativa do indivíduo e portanto regulavase segundo normas do Direito Privado. O Estado não se interessava muito "pelo labutar na economia" e, desde que introduzira, em 1869, para a Liga Alemã do Norte a liberdade profissional, apenas tratava de assuntos econômicos em decorrência de razões policiais e milita- res. $\mathrm{O}$ abandono do "estado de apadrinhamento social principesco" do século 18 , que fora sugerido principalmente por Kant foi definitivo, muito embora nem todos os ensinamentos de Kant em matéria de "Prática do Estado" e "Teoria do Estado" tivessem sido seguidos.

A indústria alemã que no decorrer da segunda metade do século 19 ganhou cada vez mais importância, criara problemas jurídicos para os quais o Direito da época, o legislador de então e os juízes não tinham nem respostas nem soluções.

Tal estado de coisas forçou o estado alemão, nos anos oitenta do século 19 a voltar a interferir com mais força na economia, tanto do ponto de vista legislativo quanto do ponto de vista de atividade empresarial própria, do estado. Estas interferências do estado alemão na economia, foram muitas e de naturezas diversas, mas ainda não baseadas em uma idéia pré-concebida, que pudesse ou devesse tomar o lugar do liberalismo econômico então vigente.

A ciência jurídica alemã teve dificuldades para enquadrar, sistematicamente, as novas formulações econômico-jurídicas. O sistema jurídico tradicional tinha alcançado, na mente dos cidadãos do século 19 , uma característica atemporal, algo perfeito e acabado. Tudo que não se adaptasse à tradição da ciência jurídica de então, era considerado de caráter apenas transitório, fenômeno de manifestação apenas momentânea e portanto passageiro.

Que este posicionamento não era sustentável e suficiente, foi reconhecido, 
como um dos primeiros doutrinadores da área, por Heinrich Lehmann. Em artigo comemorativo para Zitelman (1913) lançou as "Linhas Básicas para um Direito Industrial Alemão". Foco central da obra era a "empresa industrial". Todavia o seu enfoque era mais sócio-econômico do que considerar o fenômeno como uma grandeza jurídico-sistemática. Portanto o seu "Direito Industrial" ainda não é direito econômico e por isso ainda se situa fora dos contornos do sistema (de direito econômico) atual. A obra de Lehmann apenas sistematiza as novas normas (matéria jurídico-econômica) e os novos problemas jurídicos da empresa industrial, além de fornecer um conceito firme da nova área.

\section{O DIREITO ECONÔMICO DE GUERRA - 1914-1918}

O Direito Econômico que surgiu durante a Primeira Guerra mundial passou a questionar o sistema jurídico tradicional de um ponto de vista diferente. $\mathrm{O}$ estado passou a interferir profundamente nos processos econômicos e nas empresas, com medidas mais ou menos planificadas, a ponto de passar a administrar os recursos nacionais alemães praticamente sozinho.

"LeiAutorizadora" (Ermöchtigungsgesetz) de 04/08/1914 outorgou ao Conselho Federal um poder de legislar praticamente sem limites.Com base nesta lei, passaram a ser outorgadas todas as resoluções e regulamentos ou comunicados da época que criavam uma total administração estatal da economia alemã, abrangendo todos os bens, instituindo o controle dos preços, a criação de grande número de autoridades e organizações tais como sociedades por ações de guerra, sindicatos coativos, etc., além de baixar normas penais que deveriam dar ao todo certa segurança. A essa primeira tentativa de criar uma direção central da economia alemã (dirigismo centralizado) faltava ainda uma conceituação, pois tudo era considerado medida de emergência transitória. Consequiência disso foi o surgimento de um labirinto de organizações criadas e dirigidas pelo Estado. O marco final dessa situação, foi a administração estatal total de uma penúria total de recursos. A propriedade privada e com ela a ordem jurídica privada, foram de tal forma sobrepostas por uma "ordem coativa de distribuição", a ponto de apenas restar o que pode ser chamado de propriedade comum.

Neste estágio de emergência em decorrência da guerra, o Estado alemão tinha assumido a responsabilidade pela economia e ainda a obrigação de abastecer suficientemente seus cidadãos com bens escassos. Ocorreu então na população alemã uma mudança quanto à percepção da consciência jurídica. Outra conseqüência do direito econômico de guerra, foi a constatação, a experiência, que uma direção central da economia coloca problemas extremamente difíceis senão insolúveis. Por isso o programa pós-guerra do desmonte dos instrumentos coativos da economia foi apoiado praticamente por todos. 
Todavia a responsabilidade pela moeda ficou sendo definitivamente do Estado.

A economia livre mundial e a validade internacional do ouro, tiveram que ceder seu lugar às políticas cambiais e econômicas dos estados individuais sem que houvesse qualquer perspectiva de um sistema alternativo.

Estas profundas mudanças na economia mundial e de cada estado forçaram definitivamente que a ciência do direito passasse a confrontar-se de uma vez por todas com a questão do direito econômico.

A matéria jurídica nova que desde o início da Guerra Mundial de 1914 fora produzida, era tão vasta que praticamente não podia ser abrangida. Somente a tarefa de sistematização já era uma tarefa hercúlea. Alguns autores da época (Kahn, Nussbaum, Heymann) aceitaram o desafio da sistematização dessas novas normas, mas também nas suas obras ficava patente que o novo direito industrial ou empresarial alemão ou o novo direito econômico alemão era um corpo estranho em relação ao sistema ou ordem jurídica tradicional.

\section{A REPÚBLICA DE WEIMAR}

Sobrevém a Constituição do Império de Weimar que na parte dos direitos fundamentais ( $2^{\mathrm{a}}$ parte principal, seção 5) contém o título "A vida econômica" (Arts. 151-165).

O título inicia com as seguintes frases programáticas:

"O ordenamento da vida econômica deve corresponder aos princípios básicos da Justiça com a finalidade de garantir para todos uma existência digna para um ser humano. Dentro destes limites deve ser garantida a liberdade econômica de cada cidadão."

Com este mandamento constitucional, o Estado alemão tinha assumido uma responsabilidade abrangente para um correto ordenamento da vida econômica. Algumas linhas básicas deste correto ordenamento encontravam-se lançadas na Constituição de Weimar, embora de caráter um tanto contraditório e certamente não como modelo fechado. A reintrodução da propriedade privada e com isso a reafirmação da ordem jus-privatística, como existiam antes de 1914 era provavelmente prevista pela Constituição de Weimar lendose a frase programática acima reproduzida. Mas havia dúvidas e discussões a respeito do grau de importância que a propriedade privada e a ordem jusprivatística deveriam ocupar. Ocorre que tanto a socialização quanto a economia em comum e a democracia econômica eram idéias que também apelavam para a mesma constituição.

Os planos de socialização que após a revolução de 1918 passavam a ter um forte peso político, sem dúvida enfraqueceram e se retraíram cedendo lugar a empreendimentos de natureza de economia comum (Gemeinwirtschaftliche Vorhaben). Mas também esses somente foram implantados na exploração do carvão e do carbonato de potássio, sendo que ambos os ramos/atividades econômicas passaram às mãos de sindicatos coativos (Constituição de Weimar art. 156, alínea 2). 
O Conselho Econômico do Império, da Constituição de Weimar, não teve muito sucesso. Iniciou provisoriamente suas funções em 1920 e teve a sua última sessão plenária em 29.06.1923.

Efeitos muito maiores e mais duradouros, derivaram do novo ordenamento do direito do trabalho. Em 1918 foi introduzida a regulamentação a respeito do contrato tarifário, que fez surgir a introdução da sistemática dos contratos tarifários no mesmo ano, bem como a implantação dos Conselhos empresariais, por força da lei de mesmo nome do ano de 1920.

Estas medidas não apenas preservaram as condições básicas de uma economia livre, mas foram complementadas de forma especialmente importante do ponto de vista do direito econômico, pela Lei "contra o mau uso do poder econômico" ou "Abuso de uma posição de dominação econômica", lei essa de 02.11.1923.

O diploma legal foi promulgado pelo governo do Reich, na fase final, cheia de crises, do processo inflacionário, tendo sido considerado uma lei de emergência destinada a afastar manifestações econômicas doentias que entravavam a livre concorrência. Os cartéis todavia não foram proibidos, mas postos sob a supervisão do Ministro da Economia do Reich, bem como do Tribunal dos Cartéis.

Muito mais influentes sobre a economia alemã que as medidas legais mencionadas, foram as tremendas exigências financeiras do Estado. As grandes obrigações/tarefas que o Esta- do tinha assumido, exigiam enormes recursos. A tudo isso acresciam as exigências de reparações (dos países vencedores da $1^{\text {a }}$ Guerra Mundial) e outras consequiências/compromissos monetários derivados da Guerra. O Reich criou por isso para si uma "Administração das Finanças do Reich" e uma Lei Reguladora das Obrigações Fiscais (1919). Criou ainda, um sistema tributário próprio que resultou definitivamente no ano de 1925 nas Leis Tributárias do Reich. A consequiência de direito econômico de tudo isso foi que a participação do Estado no produto social aumentou significativamente causando ainda uma significativa influência do Estado sobre todos os processos econômicos.

Também para a empresa individual o peso dos impostos, a carga tributária, passou a assumir uma importância respeitável, influenciando as possibilidades de comportamento da empresa, o que possibilitou a contrario sensu ao Estado, dirigir de certo modo a postura das empresas através do conjunto das leis tributárias. O ministro das Finanças do Reich passou a ser conhecido como o ministro da socialização.

O primeiro teste dos instrumentos estatais de direção da economia alemã, então existentes, ocorreu durante o desenrolar da crise econômica mundial do ano de 1930. O direito emergencial já existente, com base no artigo 48 da Constituição da República de Weimar (VWR) possibilitou uma expansão legal adicional com o fito de controlar o crédito. Surge então o controle de crédito em 1931. 
Durante a curta duração da República de Weimar não se formou na Alemanha um direito econômico razoavelmente autônomo. As "teorias de conjunto" formuladas por Kahn, Nussbaum e Heymann perderam importância. Novas interpretações do direito econômico eram de cunho jurídico-teórico, metodológico, ou jurídico-político, não tão sistemáticas, que lhes rendem o rótulo "teorias de visão mundial". Resultou, que no fim da RW a questão de uma definição global do Direito Econômico continuava aberta, embora já mais tempo existissem institutos e professorados que tratassem da matéria, além do que o direito econômico já era área de formulação de provas em muitos estados alemães. Além disso a associação de juristas alemães (Deutscher Juristentag), fundada em 1921, já tinha um departamento dedicado ao Direito Econômico e ao Direito Tributário.

\section{A ÉPOCA DO NACIONAL- SOCIALISMO E A SEGUNDA GUERRA MUNDIAL}

O regime nacional-socialista (nazista) subjugou com rapidez surpreendente, bem como com atos consequientes o direito econômico, submetendo-o à sua direção ditatorial. Já em data de 15 de julho de 1933 foi publicada a Lei da Cartelização Forçada, que outorgou ao ministro da Economia do Reich poderes amplíssimos de interferência na economia. Em pouco tempo este ministério, fazendo uso dos poderes outorgados, formulou ordens regulatórias de mercado para determinados setores da economia.

A partir do ano de 1934 o ministro da Economia do Reich recebeu poderes de coação em relação às federações econômicas: tinha poderes para criá-las, dissolvê-las, preservá-las, alterar os seus estatutos, nomear e demitir os Führer (dirigentes) e outros poderes mais. Também para a agropecuária foram baixados regulamentos similares às vezes mais abrangentes ainda.

A économia alemã passou a ser dirigida com os pré-citados instrumentos e outros mais, além de ser introduzido um duro controle de divisas (moedas estrangeiras) o que passou a criar uma economia fechada, alheia aos mercados estrangeiros. A economia como um todo, passou a ser programada para o rearmamento.

Para coibir aumentos de preço que surgiam apesar do dirigismo estatal, introduziu-se em 1936 uma proibição geral de aumento de salários. As idéias de uma economia popular dirigida conforme planos estabelecidos e controlados pela sociedade, que já tinha sido cogitada na Constituição de Weimar transformaram-se em uma idéia da formação de uma economia em comum popular que se inspirava no programa de Fichte que falava de um "Estado Mercantil Fechado", idéia que datava de 1800 .

Com a eclosão da Guerra (1939) passou a ser ordenada uma administração econômica dos bens necessários à vida do cidadão e dos bens importantes para o esforço de guerra que com o 
tempo todavia se espraiou qual avalanche por todos os setores da economia como já acontecera durante a ${ }^{a}$ Guerra Mundial. Na medida em que o Estado alemão, distribuidor de bens, passou a dominar todos os setores da economia sempre utilizando os instrumentos de dirigismo criados em 1933 e cada vez mais aperfeiçoados, o Estado se tornava cada vez mais incapaz de resolver o problema a respeito dos padrões de distribuição a serem utilizados. Já que o "Princípio da quota por cabeça", da absoluta igualdade, não funcionara durante a $1^{\text {a }}$ Guerra Mundial e se mostrara injusto, passaram a ser utilizados padrões de distribuição diversificados, tais como: fatores de necessidade pessoal, valoração com base em méritos por serviços prestados para a comunidade ou então padrões de valoração política e social, além de outros. Mas nenhum desses padrões e também nenhuma combinação de padrões se revelava satisfatório. Sobrecarregada a distribuição direta, a burocracia estatal passou a ser excessivamente solicitada, o que, como já acontecera antes, também sobrecarregou o legislador eis que este constatou ser incapaz de encontrar princípios básicos corretos de distribuição de bens à população.

Os ataques do nacional-socialismo ao sistema jurídico tradicional e às concepções até então elaboradas do direito econômico, avivaram na Alemanha a discussão científica sobre o direito econômico, inclusive tornandoa mais precisa e focada. Pela primeira vez as bases do sistema jurídico tradicional eram questionadas. Principalmente o direito privado, no que tange à sua substância, era ameaçado. Para defendê-lo e juntamente com estas medidas de defesa, defender também a liberdade do indivíduo de formatar a sua autonomia privada, era necessário conceituá-lo com muito mais precisão, do que até então fora feito, no contexto de toda ordem jurídica. No entanto, dadas as circunstâncias, as questões fundamentais permaneciam controvertidas, o que teve como conseqüência que a sistematização não conseguiu passar de uma mera composição jus-positiva.

\section{OS PRIMEIROS ANOS PÓS- GUERRA}

Finda a guerra, o poder estatal da Alemanha foi dissolvido. No entanto as medidas (nazistas) de controle da economia foram mantidas e até mesmo agravadas, em virtude do aumento da escassez de tudo, em decorrência do arbítrio das autoridades das forças de ocupação e dos chefes alemães locais mantidos no poder.

O ordenamento estatal alemão futuro era incerto quanto mais a ordem econômica. Os aliados passaram a dissolver e liquidar a organização nazista da economia que ainda existia ao menos formalmente. Tais medidas correspondiam ao que fora pactuado em Potsdam a 02 de agosto de 1945, acordo que na sua parte II, art. 12 estabelecia:

"No espaço de tempo mais curto possível a vida econômica alemã deverá 
ser descentralizada, com o objetivo de destruir a excessiva concentração do poder econômico, representada especialmente por cartéis, sindicatos, trustes e outras formas de união monopolística".

Com base neste programa, parte substancial das instalações industriais alemãs foram desmontadas. Alguns ramos da economia: mineração, a indústria do ferro e do aço, a Ig Farben, os grandes bancos e a UFA (cinema) foram expropriados, para serem mais tarde segmentados ou liquidados. A liberdade de exercer uma profissão foi reintroduzida com ênfase especial na zona de ocupação americana.

Uma regulamentação geral primeira, que mais tarde se converteria no novo direito alemão, em um dos normativos mais importantes, era a que proibia as limitações da livre concorrência. Era a Lei $n^{\circ} 78$ e Regulamento $n^{\circ} 56$ das autoridades americanas e britânicas que dispunham sobre: Prohibition of Excessive Concentration of German Economic Power.

A discussão a respeito da economia alemã, entre os alemães daquele tempo (1946/1947) vinculava-se aos tempos da Constituição da República de Weimar e a grande maioria dos cientistas, juristas e economistas via nos programas daquela constituição, que nunca foram aplicados, programas tais como: socialização, economia comunitária, democracia econômica, planejamento estatal e direcionamento central da economia, marcos indicadores de caminhos futuros. A prova desta orientação encontra-se na redação de algumas antigas constituições estaduais.
A virada de orientação, que trouxe um ideário de princípios de direito econômico completamente diferente, ocorre, quando na área econômica composta pelas zonas de ocupação inglesa e americana, passou a ser possível desenvolver uma política econômica própria, alemã.Em 1948, Ludwig Erhard, como diretor da administração alemã da economia, resolveu adotar e introduzir uma política econômica de livre mercado. No dia seguinte à reforma monetária (20 de junho de 1948), Erhard anunciou, contra a vontade das forças de ocupação, o levantamento paulatino da economia forçada. A Lei sobre os princípios norteadores do desempenho da economia alemã e da política de preços, passou a formular a futura política econômica alemã, que pouco tempo depois passou a ser chamada de política livre de mercado e social. O sucesso desta decisão, que perdura até hoje, baseia-se na vivência e experiência da população alemã do mau uso da força estatal e da necessidade de impor limites a este poder estatal, bem como, do desejo de formular e moldar, por iniciativa própria, a sua vida e a vida comunitária, sem olvidar, com certeza, as responsabilidades sociais.

Por estes motivos a política econômica de Erhard teve uma influência indicadora de rumo no início da República Federal Alemã, muito embora os partidos políticos daquela época, tivessem, em parte, dificuldade em abandonar as idéias de uma economia comunitária ou de trilhar uma terceira via entre a economia de mercado e o socialismo. 


\section{A EVOLUÇÃO DO DIREITO ECONÔMICO NA ALEMANHA A PARTIR DE 1949}

Após curto período de duração, a República Federal da Alemanha desenvolveu uma ordem jurídico-econômica bastante estável e capaz de atuar, aceita pela maioria da população alemã.

A ordem não é nem estática nem doutrinária, pois permite à formatação (Gestaltung) político-econômica amplo espaço, espaço esse que durante anos não utilizou nem precisou utilizar. Embora a Constituição Alemã claramente deixou de fixar regras básicas para o Direito Econômico, não há dúvida que fixou limites marcantes: através da proteção do indivíduo e das suas possibilidades de desenvolvimento frente ao Estado, além da clara adoção de um Estado de Direito com cunho social.

A ordem econômica da República Federal da Alemanha redescobriu a propriedade privada e a autonomia privada sem descurar dos deveres de um estado social. Uma expansão do direito do trabalho e da legislação social, nivelou fortemente as diferenças de classes, que já tinham diminuído no tempo do nacional-socialismo e durante a Guerra. Sindicatos com lideranças fortes e conscientes da sua responsabilidade política contribuíram significativamente para a eliminação das diferenças de classes.

No ano de 1957, o Governo Alemão editou a "Lei contra Limitações da Livre Concorrência", considerada uma legislação nuclear do novo direito econômico alemão. Esta lei se aplica apenas parcialmente a amplos setores da economia alemã, no entanto, mesmo assim, teve o efeito de encaminhar toda economia para a livre concorrência. Muito embora a livre iniciativa voltasse a desempenhar papel importante na economia alemã, a parcela da participação estatal no produto interno bruto (PIB) continuou sendo significativa e em virtude disso permaneceu forte a influência do Estado e das corporações regionais sobre toda economia alemã, inclusive influenciando o comportamento tanto dos empresários quanto dos consumidores.

Para regulamentar os efeitos da política financeira sobre todo desenvolvimento econômico, e para implementar, além disso, uma otimização deste desenvolvimento, promulgou-se em 08 de julho de 1967 a "Lei para a Incentivação da Estabilidade e do Crescimento da Economia", alterandose através de emendas a Constituição Alemã para assim criar as bases constitucionais para estas medidas.

De acordo com estas novas regras, tanto a federação quanto os Estados alemães, têm a obrigação de elaborar e enquadrar suas medidas/leis de natureza econômica e político-financeira de tal maneira que dentro do arcabouço geral da "Ordem Econômica de Mercado" contribuem à (1) estabilidade dos preços a uma (2) alta quota de postos de trabalho (empregos) a um (3) equilíbrio da economia em relação ao exterior sempre colaborando no sentido de um (4) crescimento sustentável da 
economia alemã. Este quadrado mágico determina, portanto, a política econômica dos governos federais alemães, independentemente da sua composição político-partidária.

Uma discussão jurídico-política sobre questões fundamentais do direito econômico alemão, apenas iniciou no fim da década dos anos 60 , embora a legislação existente fosse atualizada e expandida. Assim por exemplo: as reformas dos anos 65, 73, 76 e 80 da Lei contra restrições à livre concorrência, e também da lei concernente ao estatuto das empresas (Betriebsverfassung), reformada em 1972. Todavia o estatuto geral das empresas, até então existente (Unternehmensverfassung), foi posto em dúvida, ao menos em relação às grandes empresas e às macro empresas. Passou a exigir-se um estatuto diferenciado para estas empresas, um estatuto pluralístico para os encarregados/responsáveis pela macroempresa: (Unternehmensträger). Estes esforços de reforma culminaram na lei da Cogestão (Mitbestimmungsgesetz) de 04 de maio de 1974 aplicável a todas as empresas (exceto sociedade em comandita. KG, sociedade aberta. OHG e algumas poucas outras sociedades) com mais de 2000 empregados e que determina uma composição paritária do Conselho Fiscal, com representantes dos empregados e acionistas ou sócios da empresa, mas que deixa a responsabilidade final com os acionistas ou sócios dando ao presidente do Conselho Fiscal um segundo voto.

Além disso, passou a exigir-se a instalação de conselhos econômicos e sociais nas organizações/agências federais, estaduais e regionais, igualmente com representação paritária, conselhos estes que deveriam colaborar com a elaboração de legislação, com o governo propriamente dito e com a administração pública. Como estas propostas/ exigências tocavam nos limites estabelecidos pela constituição alemã, em parte até ultrapassando os mesmos, recomeçou a discussão a respeito das possibilidades de formatação do legislador comum (não constitucional) em relação ao direito econômico.

\section{O DESENVOLVIMENTO DO DIREITO ECONÔMICO INTERNACIONAL E SUPRA- NACIONAL}

Para a Alemanha, a abertura das fronteiras para o mundo, foi igualmente importante quanto à legislação interna de direito econômico. Há uma estreita conexão com o desenvolvimento do direito econômico internacional, durante os primeiros anos após a Segunda Guerra mundial. Os Estados Unidos da América do Norte tinham tomado a iniciativa para a organização de uma ordem econômica mundial, que deveria incentivar e possibilitar, a nível mundial, a livre concorrềncia na compra e venda de mercadorias, de serviços e de capitais . As experiências negativas, então ainda recentes, com o fenômeno de estados nacionais, econômica e politicamente isolados, apoiavam os esforços dos Estados Unidos, além, da sua política anti-trust tradicional. Os esfor- 
ços americanos resultaram na Carta de Havana de 1948, que estava destinada a ser a lei fundamental do comércio mundial. No entanto, embora este documento jamais entrasse em vigor, o seu conteúdo principal i. e. a obrigação dos estados de não introduzir e obstar práticas comerciais limitadoras, teve um efeito duradouro para os países europeus que eram apoiados à época pelo Tratado do Plano Marshall (1948). O direito econômico antes limitado e concentrado numa visão acanhada da economia do próprio povo, expandiu-se, no sentido de tornar-se um direito econômico mundial ou um direito econômico internacional. Este processo de expansão passou a ser, inicialmente, uma tarefa política.

Um caminho alternativo para superar os limites de uma economia nacional, foi também encontrado nos anos que se seguiram à Segunda Guerra mundial: trata-se da formação e constituição de comunidades econômicas supra-nacionais. A Comunidade Européia do Carvão e do Aço (denominada Montanunion) que data do ano de 1951 fundada por seis estados europeus, foi a primeira. Seguiram-se a Comunidade Econômica Européia e a Comunidade Européia Atomar. As três comunidades fusionaram em 1965 os seus órgãos executivos. Em 1972 ingressaram mais três países (9) e em 1975 mais três (12), passando a contar com 12 países. Hoje já conta com 25 países.

A tarefa da Comunidade Européia de criar um espaço econômico de grande abrangência, no qual a livre concorrência (economia de mercado) pode se desenvolver sem limitações, enfrenta naturais dificuldades pois tem que lidar com valorações e regulamentações econômicas muito diferentes, em virtude das significativas diferenças e peculiaridades existentes nos diversos países-membros. O processo de integração das diferentes economias européias progride portanto na medida em que os direitos econômicos dos paísesmembros se fundamentam nos princípios e valorações de uma economia de mercado.

\section{A DISCUSSÃO CIENTÍFICA A RESPEITO DA DEFINIÇÃO DO DIREITO ECONÔMICO NA ALEMANHA}

Após a Segunda Guerra mundial houve durante um longo tempo um certo descaso quanto ao questionamento sistemático do direito econômico na Alemanha, muito embora a matéria continuasse sendo objeto de provas, testes e disciplina de ensino. Outros ramos do direito passaram a ser focalizados com mais intensidade. Assim o direito econômico administrativo e o direito econômico constitucional. $\mathrm{O}$ primeiro foi detidamente analisado por E. R. Huber em 1954 e o segundo em 1958 por Ballerstedt e Hamann.

Apenas em 1963 apareceu a primeira análise sistemática do direito econômico alemão escrita por Gerd Rinck ( $5^{a}$ edição 1977). Rinck define o direito econômico como:

"O direito do direcionamento da economia" (Wirtschaftslenkung). 
Ou então com mais detalhe:

O sistema de leis e medidas estatais destinado a dirigir, incentivar ou limitar a atividade profissional empresarial.

Outros autores também elaboraram novos conceitos sistemáticos. Assim por exemplo:

Schwark 1986

Rittner Fritz Staatslexikon 1965

Walter Schmidt Rimpler HDSW 1965

Rauschenbach, Gerhard 1965

Koppensteiner 1973

Mertens, Hans Joachim

1976

Reich

Ch. J. Meier 1982

G. Erler 1956

(Problemas básicos do direito econômico internacional)

A obra de Wolfgang Fikentscher (1983) esforça-se a aglutinar o direito econômico alemão com o direito econômico internacional e europeu num só sistema. Já o manual de Winfried Tilmann (1986) vê o direito econômico menos como "direito" e mais como um "ramo da ciência".

Do ponto de vista internacional outros autores têm contribuído à discussão.

Autores japoneses, sul-coreanos e países de vinculação românica (Itália, França, Espanha) têm contribuído significativamente à pesquisa e análise do direito econômico. Neste sentido consultar Schluep (1968).
Até 1987 os países da área do direito anglo-americano foram reticentes quanto à discussão do direito econômico de uma maneira sistemática.

Enquanto os esforços dos países do ocidente se concentram em superar as idéias jurídico-sistemáticas do século 19 e de se acoplar ao desenvolvimento do direito dos dias atuais e do futuro, os países da Europa Oriental, principalmente a Rússia, ainda se debatem com a questão de dar ou não dar à empresa liberdades de uma economia de mercado. Continua forte na Rússia a "Escola de Direito Econômico Administrativo" que vê as empresas como parte do aparelho administrativo do Estado. Esta problemática tem alto significado político e a tendência do Presidente Russo Putin é de dar razão a esta escola diminuindo assim as chances de se estabelecer na Rússia uma verdadeira economia de mercado.

Quanto à definição de direito econômico, especialmente seu relacionamento a outros ramos ou áreas do direito, como já dito anteriormente, não há um consenso. Alguns pesquisadores se resignam e apenas aceitam como sendo possível uma interpretação aberta do direito econômico, renunciando a uma delimitação normativa. Assim Chr. J. Meier, (1982). Contrário a este posicionamento, o prof. Fikentscher propõe a seguinte definição que, no entanto, é muito complexa:

direito econômico é aquele conjunto de normas importantes do ponto de vista do direito, que regula a liberdade 
do câmbio de acréscimos/poupança e da inclusão/destinação de bens economicos, através de princípios gerais e fundamentais, bem como por meio de intervenções globais ou especiais, a fim de garantir aos "cidadãos econômicos" uma auto-determinação equilibrada, bem como um abastecimento satisfatório, segundo os padrões de justiça econômica e dentro dos parâmetros de uma constituição econômica pré-estabelecida.

Esta definição tenta, sem dúvida, uma sistematização jurídica, mas alargase para uma visão problemática com acentos programáticos, pouco contribuindo, por isso, a uma fixação de limites do direito econômico em relação a outras áreas do direito.

Que esta tentativa de definição do D.E., bem como outras, pouco satisfaçam, tem a sua razão de ser em que nenhuma delas caracteriza exatamente a tarefa e função da sistemática jurídica.

As definições apresentadas olvidam de um lado que não existe uma sistemática do direito supra-temporal, quer dizer, toda categoria jurídicosistemática é condicionada historicamente e é mutável, tanto quanto o direito que se procura sistematizar. Por outro lado, não se dão conta os autores que é impossível dividir as normas jurídicas - mesmo as de uma única ordem jurídica - em um sistema bidimensional, quer dizer, segundo os princípios básicos da divisio (differentia specifica, genus proximum) mas sim que a tarefa exige um pensar sistemático multi-dimensional.

\section{O DIREITO ECONÔMICO COMO UM CONCEITO SISTEMÁTICO. \\ O DESENVOLVIMENTO DO CONCEITO. A TAREFA DA SISTEMÁTICA DO DIREITO}

Sistematizar significa ordenar, membrar, compor. Os princípios da sistematização devem corresponder, objetivamente, ao material que se propõe sistematizar. Considerando que o Direito, segundo a sua natureza sui generis se compõe de normas mandamentais (Sollenssätzen) ou imperativas, as conexões entre as diversas normas e conseqüentemente também os princípios de sistematização devem ser apenas de qualidade mandamental, devem portanto situar-se no normativo.

Isto vale, de qualquer forma, para a sistemática jurídico-científica. A prática do direito, todavia, não fica impedida de procurar proposições próprias, de natureza prática e de membrar, organizar o direito em áreas de vivência (Lebensgebieten) ou em sub-sistemas sociais como por exemplo "O direito do comerciante individual", o "direito do odontólogo/dentista" ou o "direito da agronomia".

$\mathrm{O}$ que estabelece a conexão entre as normas individuais e os diversos institutos, são as valorações específicas, os princípios e os raciocínios de que aquilo que se está fazendo está certo/ correto (Richtigkeitsgedanken).

Assim por exemplo encontramos como princípio global de conexão de todo direito privado, o princípio da Autonomia Privada. 
Tudo decorre (no Direito Privado) do princípio básico que os indivíduos devem formatar, construir, as suas relações jurídicas eles próprios.

Em uma ordem jurídica relativamente complexa/complicada, existe um grande número de tais valorações e princípios básicos que além disso tem significados diferenciados e que com o passar do tempo se modificam nas suas relações e significados.

Por isso, não é possível representar o sistema do direito de acordo com ou dentro de um sistema de mera coordenação que se contenta com duas ou três dimensões.

As múltiplas e importantes valorações, princípios e raciocínios no sentido do correto que se manifestam em um moderno sistema jurídico, se relacionam de forma tão complexa que não é possível representá-los graficamente pois somente podem ser pensados. Para simplificar o raciocínio e a apresentação limitamo-nos, no processo de sistematização a algumas poucas valorações que são especialmente importantes para as tarefas concretas de sistematização. Por isso o verdadeiro problema é a escolha dessas valorações, considerando que a ordem jurídica muda constantemente.

\section{O RACIOCÍNIO DE VALORAÇÃO DO DIREITO ECONÔMICO}

O raciocínio de valoração do direito econômico jamais foi positivado melhor no direito alemão do que pelo artigo 151 da Constituição do Império de Weimar WRV.

Ali encontramos a seguinte normatização:

O Estado tem a responsabilidade de garantir que a vida econômica (na Alemanha) corresponda aos principios de justiça, especialmente à garantia de uma existência (humana) digna para todos (os cidadãos).

Tal enunciado, segundo Rittner não significa em absoluto que o estado tem a obrigação de implementar estes objetivos e valorações ele próprio, diretamente, ou através de atos legislativos, leis, atos administrativos, isto é, soberanamente. Muito pelo contrário, a Constituição do Império de Weimar (WRV) já nos artigos seguintes ao 151, utilizase dos principais elementos da autonomia privada-liberdade de contratar, propriedade, direito de suceder, para integrá-los no processo de obtenção das citadas garantias estatais.

Tal posicionamento de um lado já previne a tentação do estado moderno de arrebanhar para si um excesso de competências soberanas. De outra parte os citados artigos da WRV integram os mencionados institutos do direito privado no conjunto normativo relacionado da ordem econômica global.

A liberdade de contratar e o direito à propriedade e todos os demais institutos caracterizadores do direito privado, passam a ter uma dupla função; sua tarefa na órbita do direito privado de induzir e garantir uma ordem justa entre os indivíduos quer dizer (por exemplo, 
entre o comprador e o vendedor, entre o locatário e o locador) passa a expandir-se, passa a ter um significado/sentido adicional e uma tarefa adicional, isto é, servir de instrumento para que uma ordem econômica global correta possa concretizar-se com as inevitáveis exigências de tolerância (como ocorrem no direito privado). Tais institutos privados, integrados, não mais têm funções meramente privadas, mas também públicas, quer dizer funções que se estendem à ordem econômica geral de um país.

Este novo raciocínio/pensar valorativo do direito econômico, em contraste com o raciocínio em voga antes das guerras mundiais, afeta igualmente as regras e regulamentações, até então nitidamente privatísticas. O legislador e os tribunais modificam e amplificam, em virtude dessa nova valoração, o direito advindo de uma época anterior e diferente, o direito do século 19.

A utilização de institutos importantes do direito privado para a correta e completa substanciação do direito econômico, não é um absoluto, um procedimento meramente técnico-jurídico, comparável, por exemplo, com a mera recepção de conceitos de direito privado pelo direito administrativo. Não, ela repousa acima de tudo no fato que o Estado, também o Estado Social, deve deixar o "laborar na economia" (Wirtschaften) fundamentalmente a cargo do indivíduo, do cidadão individual, se o Estado, como Estado de Direito, deseja garantir a liberdade e a igualdade dos seus cidadãos. Como foi ampla- mente provado e demonstrado, ao longo dos anos, o Estado, ele próprio, não têm condições de assumir mesmo apenas quanto à aspectos substanciais, o desempenho da economia de um país. Portanto, o Estado não pode, assumir esta função de "laborar na economia", nem do ponto de vista organizacional, nem tendo em vista a liberdade dos seus cidadãos. Se então, o agir economicamente do Estado, deve manter-se, dentro de limites, mesmo se democraticamente legitimado, resta a formatação da economia, fundamentalmente pela atuação do indivíduo, do cidadão, nitidamente a cargo da atuação na esfera autônoma e privada.

A formatação (Gestaltung) da economia pela atuação do cidadão individual, dentro da esfera autônoma e privada baseia-se no princípio da igualdade. Por outro lado, o poder soberano necessita e se fundamenta na legitimação democrática. O princípio da igualdade significa que toda pessoa física como pessoa de direito e com direitos se iguala à outra pessoa física com direitos. O indivíduo como cidadão do Estado e o indivíduo como pessoa de direito e com direitos são as duas figuras básicas, fundamentais, do direito econômico alemão. Delas decorrem todas as demais funções, como por exemplo a administração estatal da economia decorre da legitimação democrática, como o agir como empresário se origina na autonomia privada e na garantia da propriedade. Outros princípios de ordenação não interessam a um ordenamento jurídico-econômico de 
uma sociedade que se baseia nos princípios que informam e garantem a igualdade de todas as pessoas. Assim por exemplo não interessa mais o sistema feudal da Idade Média, nem sistemas similares (ao feudalismo) como o sindicalismo.

\section{O DIREITO ECONÔMICO NO DIREITO COMPARADO}

O marco de direito positivo estabelecido no direito constitucional alemão v.g. pela Constituição do Império de Weimar (Weimarer Reichsverfassung) no art. 151 é o caminho enveredado pela maioria das ordens jurídicas de cunho libertário das últimas décadas. Umas mais consciente e determinadamente, outras menos assim. Muitas ordens jurídicas ainda não elaboraram uma categoria especial do direito econômico. Isto todavia não significa, necessariamente, que, objetivamente, o direito econômico daquele país é menos desenvolvido. Muito depende do tipo de raciocínio de direito sistemático. Assim, por exemplo, o sistema (jurídico) do século 19 , tem nos países europeus, principalmente na Alemanha, uma força de tal forma marcante e dominadora, que todas as valorações econômicas não teriam, não encontrariam um local de fixação no sistema, se o sistema jurídico tradicional do século 19 não fosse complementado pelo direito econômico.

Assim, a milenar divisão do direito (desde o tempo dos romanos), em direito público e direito privado, que ainda é considerada fundamental, embora já muito questionada, em virtude da sua tradicional inelasticidade, exige esta complementação, antes mencionada, pelo direito econômico, que em verdade opera uma simbiose parcial dos dois tradicionais ramos do direito.

O direito econômico supera a divisão tradicional do sistema jurídico em direito privado e direito público, ao propiciar e viabilizar o concerto de regras da autonomia privada com regras soberanas (estatais). Este concerto ou "mix" muda, de país para país. Os direitos econômicos ocidentais deixam a organização e os processos econômicos, fundamentalmente à ação dos e formatação pelos particulares (Privatautonome Gestaltung) que todavia passa a ser regulamentada de maneira mais ou menos intensiva por regras, elementos soberanos (Hoheitliche Elemente) como por exemplo normas coativas, cooperação/ ação conjunta dos tribunais/juízes ou das autoridades; exigências de licenças/ permissões/alvarás/certificações, poderes de supervisão, etc, de maneira que possam ser corrigidas tendências desenvolvimentistas grosseiramente erradas ou até mesmo situações totalmente erradas.

Os direitos econômicos do leste europeu, ex-estados comunistas, ainda são regulamentados e organizados, via de regra, por normas estatais soberanas, e deixam à formatação do labutar na economia, pelo cidadão individual e pelas empresas, relativamente pouco espaço e oportunidades. Enquanto nas economias socialistas/comunistas as 
necessidades de recursos do Estado e o abastecimento da população são sempre preocupação principal, nos países do centro-oeste europeu, há prioridade para garantir o desenvolvimento profissional e pessoal dos cidadãos que satisfazem as suas necessidades de bens/serviços e recursos na base da troca contratual, enquanto os estados do ocidente satisfazem as suas necessidades de obtenção de recursos por meio da arrecadação de impostos.

\section{DEFINIÇÃO}

O direito econômico engloba e abrange portanto aquelas normas e institutos que viabilizam, concretizam toda ordem econômica. O direito econômico abrange ainda a organização e o comportamento das empresas nos mercados, bem como as funções correspondentes do estado.

Quase todas as normas e institutos do direito econômico desempenham funções e produzem efeitos em outros ramos do sistema jurídico, assim no direito administrativo, no direito constitucional, no direito contratual, no direito societário e no direito das minas.

$\mathrm{O}$ enfoque e a compreensão das normas é bifocal ou bipolar. Assim, no seio do direito econômico, estas normas funcionam e são compreendidas como parte integrante do correto e completo sistema da ordem econômica, enquanto nos demais ramos do direito, as valorações do direito administrativo, constitucional, contratual, societário e do direito das minas se encontram ressaltadas e se sobrepõem.

\section{A COMPOSIÇÃO/}

ARTICULAÇÃO DO DIREITO ECONÔMICO ALEMÃO ATUAL

A articulação e os limites de uma área do direito resulta do relacionamento das diferentes valorações do direito positivo. O raciocínio valorativo específico do direito econômico, é a correção, justeza de toda economia, isto é: a ordem mais justa possível da vida econômica de uma nação.

Em um sistema jurídico que não se fundamenta exclusivamente sobre uma constituição escrita mas que confia e entrega a constituição a uma corte especializada, todo ramo jurídico do direito deve ser compreendido, em primeira linha, a partir das suas bases constitucionais.

Esta deve ser, portanto, também a base do direito econômico.

\section{O DIREITO ECONÔMICO GERAL E O DIREITO ECONÔMICO ESPECIAL}

Muitas normas jurídicas valem para toda economia, outras valem apenas para determinados ramos da economia. Assim por exemplo a GWB Lei Contra Limitações da Livre Concorrência, vale para e é aplicável a todas as empresas, embora apenas parcialmente relativamente a empresas de determinados ramos da economia.

Já para os setores especializados, da economia tais como: seguros, crédito e energia, entre outros, há legislação especial. 
$\mathrm{Na}$ área do direito econômico geral, as normas estatais soberanas têm prevalência, eis que determinam os limites da formatação autônoma privada do "labutar na economia". A legislação, o governo e a Administração têm na área do direito econômico geral tarefas e funções específicas que não são alcançadas pelo direito do estado e pelo direito administrativo.

O contorno institucional mais importante do direito econômico geral, é traçado pelo direito empresarial.

Toda ordem econômica que deixa, por questão de princípio, para o cidadão individual o agir, labutar na economia, excluindo o Estado e outras instituições estatais, é obrigada a elaborar regulamentos que determinem como os responsáveis pelas empresas (Unternehmens traeger) devem se organizar e decidir a quem vai permitir ser empresário de maneira geral ou especial. Deve ainda decidir se, eventualmente, e sob quais condições o Estado e as corporações regionais de cidades podem agir de forma empresarial. Mais adiante analisaremos a importância dos bancos estaduais na Alemanha.

Enquanto o direito empresarial e o direito das funções soberanas fixam os contornos institucionais do direito econômico geral, há que regulamentar os processos que se desenvolvem entre as empresas e seu comportamento frente à legislação que proíbe quaisquer limitações à livre concorrência.

Uma ordem econômica, que por questão de princípio deixa o agir na economia à iniciativa privada, à auto- nomia privada do cidadão, não pode deixar de proteger o princípio da livre concorrência dos conchavos e das combinações limitadoras e práticas semelhantes de empresários inescrupulosos que tolhem a livre concorrência. Destarte, o direito à livre concorrência torna-se a peça nuclear de todo direito econômico. Nesse contexto, a moderna legislação reguladora dos cartéis a GWB e os regulamentos complementares na legislação européia desempenham um papel determinante. A par disto, a inclusão neste esquema legal, da legislação contra a concorrência desleal ( $U W G=$ Gesetz Gegen den Unlauterten Wettbewerb) é uma questão não tanto de cunho sistemático, mas sim de praticidade.

Ao fim e ao cabo o direito econômico geral deve preocupar-se com o tema/questão da direção da economia, isto é, com o instrumental que é utilizado para dirigir a economia.

A direção da economia utiliza como instrumental normas soberanas e outras medidas que se destinam a regulamentar e ordenar objetivos específicos pré-determinados pelo Estado. Este conjunto de normas adquire sua praticidade e efetividade, principalmente, no âmbito do direito econômico especial. Sua intensidade aumenta, na medida em que os regulamentos especiais setoriais se afastam dos instrumentos de direção usuais e regulares utilizados no âmbito do direito concorrencial. O direito geral/ comum de direção da economia engloba estes regramentos especiais, notadamente as normas de supervisão, de 
subvenção e de controle de preços. Abrange ainda as normas do direito dos emergenciais, isto é: a administração geral vinculada diretamente à direção estatal da economia em situações de emergência.

Do todo até aqui examinado, emerge o seguinte esquema para todo direito econômico:

1 - Bases/fundamentos constitucionais

2 - Direito econômico geral

a) as funções soberanas do direito econômico

b) o direito empresarial

c) o direito contra as limitações da livre concorrência

d) o direito geral da direção da economia

3-O direito econômico especial esquematizado segundo as regulamentações dos diversos setores da economia.

\section{DO RELACIONAMENTO ENTRE O DIREITO E A ECONOMIA}

Li com atenção, os diversos artigos publicados na Revista Direito e Economia, $1^{\text {a }}$ edição, junho de 2005 , coordenador prof. Luciano Benetti Timm, Editora Thomson / IOB. Vários dos autores, de uma ou de outra forma, registram e lamentam, com maior ou menor intensidade, a falta de comunicação e entrosamento entre os economistas e juristas. Afirmam os articulistas que os cultores destas duas ciências, não se entendem e que existe. por assim dizer, um diálogo de surdos.
Decididamente não é a minha opinião e discordo deste posicionamento. Entendo que do lado dos advogados, dos juristas que lidam e atuam em posições políticas e administrativas governamentais, há um conhecimento seguro, no sentido que para obter resultados práticos na área econômica, para dirigir, enfim, a economia de um país ou de uma região, em ou para determinado sentido, é preciso elaborar leis, regulamentos, diretivas que determinem, legalmente, o rumo que as operações, negócios ou mesmo setores inteiros da economia devem tomar. Os exemplos disso estão em toda parte. No direito tributário, do trabalho, societário, falimentar, cambiário, na área do direito bancário, financeiro, do mercado de capitais, no direito imobiliário, securitário, etc. Sempre são propostas e elaboradas leis, normas enfim, com o fim de fixar determinados rumos nas áreas citadas que serão importantes para o desenvolvimento da economia. Portanto os advogados e juristas sabem usar a lei, as normas, para através do direito econômico influenciar, dirigir a economia. Também os economistas sabem que na maioria das vezes, precisam do instrumental jurídico para, na economia, conseguir chegar onde desejam chegar. $\mathrm{O}$ mesmo vale para o administrador público, tenha ele inclinações democráticas ou não. Sempre precisará da lei para obter os resultados que deseja alcançar, sejam bons ou maus, democráticos ou ditatoriais. Logo concluo que tanto o economista quanto o jurista, sabem muito bem que necessitam da lei, da norma imperativa, para, de qualquer 
forma, dirigir a economia. Sem dúvida existe o mercado e a realidade das ofertas e procuras, mas em pleno século 21 , a mão invisível reguladora do mercado/economia, da qual falava em 1776 Adam Smith, esta já não é mais tão invisível assim, pois já não existe mais mercado totalmente livre, sempre há ou haverá alguma lei, alguma norma, atuando ou pronta para atuar, a fim de corrigir as falhas (da mão invisível regulamentadora) do mercado. Então, vista a problemática do relacionamento entre a economia e o direito assim, deste ponto de vista pragmático, não há dúvida nenhuma para nós, que tanto os economistas quanto os juristas sabem muito bem, que para dominar, enquadrar, regulamentar, dirigir, formatar a economia é preciso ter leis e normas que viabilizem e possibilitem a dominação, enquadramento, regulagem, formatação e direção da economia.

Vamos dar um exemplo, a nosso ver muito simples. Todos sabemos que o princípio mestre da economia de mercado livre é o princípio da livre concorrência. Onde inexiste livre concorrência apenas existirão cartéis e monopólios. Então, para assegurar a existência de um mercado "livre", para assegurar a livre concorrência entre as empresas produtivas, no interesse dos consumidores, é necessário intervir com a lei no mercado e coibir, proibir os cartéis e os monopólios, dirigindo e formatando assim a economia, já que a tendência natural do empresário produtor, livre de quaisquer controles legais é de eliminar a concorrência e adonar-se do seu segmento de mercado, dominando-o em detrimento do cidadão consumidor. Não é pois possível deixar rédeas totalmente livres aos atores no mercado, na economia, sob pena de total destruição e extinção deste mesmo "livre mercado". Conclusão: nenhum mercado é totalmente livre, sempre haverá e deverá haver alguma norma reguladora para exatamente assegurar que este mercado, ou segmento dele, continue livre e útil ao consumidor. Dito isto, pareceme que o jurista, ao menos aquele mais ou menos versado em economia e administração pública, sabe muito bem da importância da lei, da norma, para poder obter efeitos no desempenho da economia. Não há diálogo surdo, inexistência de conhecimento; muito pelo contrário, existe um controle mais ou menos intensivo da economia através das normas, do direito econômico que são manejadas tanto pelos juristas, quanto pelos economistas e políticos.

\section{O DIREITO ECONÔMICO E OS DEMAIS RAMOS DO DIREITO}

Por ser uma disciplina nova, o direito econômico deve traçar com clareza os limites em relação a outros ramos do direito. Isto não significa todavia, que, o direito econômico deve entrar em litígio com outro ramo do direito relativamente a essa ou aquela norma ou a esse ou aquele instituto. Considerada a diversidade de pontos de vista numa sistemática do direito, é perfeitamente possível que uma norma ou um instituto apareça em vários ramos do direito. 
Assim por exemplo a sociedade do BGB encontra-se tanto no direito obrigacional do direito civil alemão (BGB II Livro, seção 8) quanto no direito societário alemão. Similarmente a confissão de dívida nominativa e ao portador (Inhaber und Orderschuldverschreibung) aparece tanto no direito obrigacional do direito civil alemão quanto no direito cambiário e, além disso, na legislação dos negócios bancários.

Em relação ao direito privado em geral, o direito econômico se diferencia pelo seu próprio princípio de valoração. Enquanto que no direito privado a característica (valoração) marcante é o relacionamento de uma parte com a outra, no direito econômico sobressai a valoração da justeza (Gesamtwirtschaftliche Richtigkeit) da totalidade da economia. Do ponto de vista do direito econômico, os institutos centrais do direito privado, contratos e propriedade, passam a ter um outro sentido e uma outra função. Passam a caracterizar uma ordem econômica descentralizada que se fundamenta sobre a autonomia privada e sobre a propriedade dos cidadãos, sendo que a ordem econômica thes concede, permite, basicamente a produção dos bens, e a sua distribuição. A outra opção, ou o outro caminho que a ordem econômica poderia percorrer, ao formatar a economia globalmente, seria a sua formatação - Gestaltung - pelo estado, soberanamente, por intermédio de órgãos estatais ou pára-estatais que passam a produzir e a distribuir os bens dos cidadãos.

Se a escolha do legislador for pela instituição de uma ordem econômica descentralizada, o instrumental / normas e institutos / privatístico passa a integrar o direito econômico. No caso dos contratos, por exemplo, o direito econômico não se preocupa com a justeza do posicionamento contratual de uma parte em relação à outra, mas, sim se o contrato está correto no contexto geral da economia, se por exemplo ele influencia positivamente as relações do mercado. Sempre deverá estar presente o princípio básico da livre concorrência, que, se necessário, deverá ser reforçado por elementos soberanos. Os exemplos citados mostram, que o direito econômico integrou, recepcionou, os principais institutos do direito privado na sua sistemática, fazendo deles instrumentos da formatação - Gestaltung - jurídico-econômica da economia global de um país. A complementação da ordem privatística autônoma por elementos reguladores soberanos desempenha aí um papel importante.

Seguidamente o direito econômico entrega ou deixa tarefas de economia global à ordem privatística autônoma, por motivos constitucionais.

Os elementos reguladores soberanos utilizados pelo direito econômico na formatação global da economia são por exemplo: autorizações governamentais, licenciamentos, controle por auditores externos, publicidade obrigatória, etc. As normas e os institutos de direito privado cooptados pelo direito econômico passam a ser encarados exclusivamente do ponto de vista do direito econômico e não mais do ponto de vista de direito privado. Este mecanismo de 
utilização de normas de um setor do direito positivo por outro, já era conhecido, por exemplo, em relação ao direito comercial e direito civil. Em matéria de contratos e obrigações e modos por que se dissolvem e extinguem as obrigações comerciais, por exemplo, o direito comercial (parte ora revogada pelo Novo Código Civil) utilizava normas do direito civil e as especializava para as afeiçoar às suas necessidades. Era o caso dos artigos 121 e 428 da parte revogada do Código Comercial.

Esta simbiose parcial e pontual entre o direito privado e o público é captada e analisada pelo prof. dr. Fábio Nusdeo em sua magistral obra Curso de Economia - Introdução ao Direito Econômico (2a ed. RT) Capítulo 10.

Ensina o prof. Nusdeo:

As limitações de mercado e a colocação de objetivos de politica econômica levaram os sistemas descentralizados ocidentais a evoluírem no sentido de admitir, em caráter permanente, um segundo centro decisório a atuar ao lado do mercado, descaracterizando-se como modelos típicos de autonomia, longe, porém, do outro extremo, o da centralização pela autoridade política. Daí as expressões sistemas mistos ou de iniciativa dual, ambas felizes por retratarem a nova realidade.

Reconhece o prof. Nusdeo o direito econômico como o direito da política econômica. Reconhece ainda o direito econômico como um ramo jurídico, assinalando que no Brasil esta característica é "consagrada pelo art. $24, \mathrm{I}$ da $\mathrm{CF}$, quando atribui à União e aos Estados competência concorrente para sobre ela (direito econômico) legislar (obra citada p. 205).

"Trata-se, no entanto, de um ramo sui generis, ou seja, tem uma particularidade toda dele, que deriva do fato de as suas normas, em grande número de casos, estarem inseridas formalmente em outros ramos jurídicos, marcando-os porém com o seu caráter específico de normas instrumentais de políticà econômica. É o caso de normas sobre reajuste de aluguéis, que incidem sobre uma relação típica de Direito Civil, como é a locação de prédios. Idem quanto ao chamado dirigismo contratual, isto é, determinações cogentes quanto a cláusulas que devam ou não constar de contratos privados de caráter civil ou comercial - caso típico de ação estatal por direção na classificação de Grau. O mesmo quanto ao processo decisório para a construção de uma estrada para escoamento de produtos de exportação, como na hipótese discutida ao fim do capítulo anterior. Aí, trata-se de uma medida de política econômica interferindo no campo do Direito Financeiro. É, ainda, o caso dos incentivos fiscais de toda a ordem, a trair uma política econômica que, em princípio, contraria a vocação natural do Direito Tributário: a de cobrar impostos e não deixar de fazê-lo. Mais um exemplo: as legislações antitruste ou ambiental, inseparáveis das considerações ou opções de política econômica."

"Tanto essa característica das normas de Direito Econômico é importante 
e saliente que um autor italiano, Finzi, o vê sinteticamente como um taglio trasversale, isto é, um corte transversal na árvore do Direito, como que seccionando os seus vários ramos para matizálos com um colorido diverso, uma marca especial que antes não ostentavam. Ele é, assim, um ramo intromissor com relação aos demais, mas não estranho à árvore, porque sai diretamente do tronco constitucional, precisamente da chamada constituição econômica, referida no capítulo anterior. Um outro autor, este francês, Jeantet, usa uma imagem análoga, sendo as suas manifestações de permeio a todo ordenamento algo como as correntes marítimas no meio dos oceanos. É, em suma, um direito de sobreposição, por se sobrepor a outros ramos jurídicos na regulação de determinadas relações sociais."

"A dificuldade resulta do fato de a árvore jurídica, tal como vista nos sistemas ocidentais, estar baseada na chamada summa divisio de Ulpiano, a qual, como ressaltado no Capítulo 6, coube como uma luva para a edificação jurídica do sistema liberal, procurando distinguir tão absolutamente quanto possível o publicum do privatum. A simples idéia de um direcionamento do privatum em prol dos objetivos do publicum já discrepa da natureza e da essência daquela visão de Ulpiano, origem, também, da imagem da árvore jurídica, perfeitamente acomodada ao paradigma liberal mas não confortavelmente abrigada por uma mutação substancial do mesmo."
E mais adiante registra Fábio Nusdeo:

Dentro dessa visão, é imprescindivel tecer a distinção entre a norma de Direito Econômico e o mero conteúdo econômico da norma jurídica. Como sabido, tal conteúdo encontra-se na esmagadora maioria delas, mas o caráter de Direito Econômico lhes é imprimido pelo sentido de vetorialização que assumem quando voltadas à colimação de objetivos de política econômica.

Em relação ao direito comercial e ao direito societário, a diferenciação em relação ao direito econômico é similar à que ocorre em relação ao direito civil. Importam os princípios de valoração, prevalentes em cada ramo do direito. O direito comercial negocial, o direito cambiário e também o direito do comerciante propriamente dito (HGB Livro I, Seção 1-4), bem como o direito societário, são regidos por valorações que se limitam a regular corretamente os interesses individuais de que tratam. Assim temos por exemplo: a regulamentação das relações entre o comerciante e seus credores; dos sócios entre si, e em relação aos credores da sociedade e de seus sócios. Até mesmo a regulamentação do registro mercantil, das normas contábeis e dos balanços, com as suas obrigações de direito público, não fazem exceção.

Quanto à lei das sociedades por ações, regulamenta, via de regra, toda a sua área de incidência do ponto de vista das relações individuais/coletivas 
dos sócios. Todavia, na lei das sociedades por ações, surgem situações de direito econômico que são levadas em conta e por ele resolvidas. É de assinalar que questões nesta área que interessam a toda a economia de um país, não são resolvidas dentro ou pelo direito comercial ou societário, mas sim pelo direito econômico. Assim, por exemplo as seguintes questões: a quem é lícito exercer esta ou aquela atividade profissional; grandes empresas obrigatoriamente devem revestir a forma de S/A?; negócios bancários ou securitários somente podem ser realizados por determinadas sociedades?, o Estado e as comunidades podem empreender? Podem formar e operar empresas/sociedades, competindo com as particulares? Se ao lado dos sócios/empresários e seus representantes outras pessoas podem ativamente participar na formação da vontade do(s) responsável(eis) pela empresa. Por exemplo: representantes dos empregados, representantes do estado ou representantes do interesse público. Na República Federal da Alemanha, os Estados federados operam, por exemplo, bancos estaduais, competindo com os bancos privados em todos os negócios bancários.

Os bancos estaduais na Alemanha (Landesbanken) são institutos de crédito ou instituições financeiras que atendem os negócios bancários de um ou mais estados federados e que apóiam os governos estaduais na incentivação da economia estadual. Atendem, pois, um interesse (Offentlichen Auftrag) ou melhor, uma missão pú- blica. Nos termos dos seus estatutos, estes bancos estaduais praticam todos os negócios bancários permitidos e se apresentam no mercado bancário como bancos universais ou multibancos (Universal Bank, Allgemeine Geschäftsbank). Os bancos estaduais alemães, tradicionalmente são também bancos comunitários e atuam em conjunto com as caixas econômicas regionais. Os controladores responsáveis (Träger) são os estados e as associações de caixas econômicas. O banco estadual alemão é o instituto central das caixas econômicas de um estado federado. São portanto também a central de acerto de contas (clearing house), para os negócios não a contado, além de administrarem as reservas de liquidez das caixas econômicas vinculadas/associadas; praticando ainda operações de refinanciamento emitindo títulos de penhor (Pfandbriefe) e obrigações/debêntures comunitárias. Prestam também serviços bancários internacionais para os clientes das caixas econômicas.

Com poucas exceções (exemplo: a HSH Nordbank AG) os bancos estaduais estão submetidos ao controle estadual dos respectivos estados federados.

Os bancos estaduais alemães participam do capital de outros bancos estaduais.

Assim a Westdeutsche Landesbank $A G$ (West $L B A G$ ) detém $26 \%$ do capital da HSH Nordbank AG (antigos bancos estaduais), Hamburgische Landesbank e Landesbank Schleswig - Holstein. A Norddeutsche Landesbank - Nord/LB participa com $10 \%$ do capital da Landesbank Berlin LB Berlin e 
com $97 \%$ do capital da Bremer Landesbank Kreditanstalt Oldenburg. A Bayerische Landesbank Bayern LB participa com $75 \%$ do capital da Landesbank Saar - Saar $L B$ e finalmente a Landesbank Badenwürtemberg - $L B B W$ controla $100 \%$ o capital da Landesbank Rheinland - Pfalz - LRP.

Desde o início da década de 70, os bancos estaduais alemães concedem, por conta própria, créditos aos seus clientes. Tal prática passou a ser criticada publicamente pela concorrência bancária privada, que passou a alegar que os bancos estaduais tinham forte influência política em virtude dos seus controladores serem os governos estaduais. A defesa apresentada a tais críticas foi no sentido que se desejava alcançar e realizar fins e propósitos de estrutura econômica política, do interesse do estado.

Além disso, a concorrência alegava que, embora a concessão de créditos dos bancos estaduais fosse submetida às mesmas normas e exigências da lei federal do crédito (Kreditwesengesetz), válida tanto para as instituições financeiras privadas quanto públicas, os bancos estaduais gozavam da vantagem da capitalização através do orçamento público dos estados.

As reclamações dos bancos privados foram encaminhadas a Bruxelas, alegando distorções do regime de livre concorrência. Firmou-se um acordo em Bruxelas em julho de 2005, intitulado "concordância de Bruxelas".

Existem onze bancos estaduais na Alemanha:
- Bremer Landesbank Kreditanstalt Oldenburg - Girozentrale (92,5\% Hält die Nord/LB);

- HSH Nordbank AG, Hervorgegangen aus der Hamburgischen Landesbank und der Landesbank Schleswig-Holstein Girozentrale;

- Landesbank Berlin (LBB);

- Landesbank Baden-Württemberg (LBBW);

- Helaba - Landesbank HessenThüringen - Girozentrale;

- Nord/LB-Norddeutsche Landesbank - Girozentrale;

- West LB AG - Westdeutsche Landesbank - Girozentrale;

- Saar LB - Landesbank Saar Saarbrücken;

- Sachsen LB - Sächsische Landesbank - Girozentrale;

- Bayern LB - Bayerische Landesbank - Girozentrale;

- LRP -Landesbank RheinlandPfalz (100\% Hält die Landesbank Baden-Württemberg).

A diferenciação entre o direito econômico, o direito administrativo e o direito constitucional é particularmente importante, pois existem o direito constitucional econômico e o direito administrativo econômico.

A constituição normativa é a ordem jurídica fundamental da existência comunitária, segundo cujos princípios básicos se forma a unidade política e se estabelecem as tarefas do Estado. Portanto o direito constitucional econômico é parte da constituição. Contudo é perfeitamente possível que seja também considerado parte do direito 
econômico, mais do que isso, pode ser considerado o fundamento constitucional do mesmo. Exemplo: o princípio da liberdade do exercício profissional é um tema constitucional, um direito fundamental ancorado no art. 12 da Constituição alemã. Mas é também tema e assunto do direito econômico, pois decide o acesso à atividade empresarial e o acesso aos mercados em geral.

O direito administrativo engloba todo o direito pertinente à administração pública, aí incluídas as suas competências soberanas. Uma parte da administração pública diz respeito a regulamentações que tem como destino toda economia de um país, exemplo: a autoridade federal controladora dos cartéis (Bundeskartellamt); a autoridade federal supervisionadora do sistema securitário (Bundesaufsichtsamt für das Versicherungswesen); a autoridade federal supervisionadora do crédito (Bundesaufsichtsamt für das Kreditwesen). Destarte estes segmentos especiais do direito administrativo, com características de direito econômico, devem ser respeitados e integrados na sua totalidade pelo direito administrativo, para garantir a unidade do setor e a justeza da administração pública. Já o direito econômico vê estes órgãos e as suas normas reguladoras no contexto das suas próprias valorações específicas, que determinam os alvos e também os meios de que se serve o direito econômico.

Em relação ao direito do trabalho e ao direito tributário, o direito econômico também se diferencia por força das tarefas que lhe são próprias. Embora pareça que o direito do trabalho nada tenha a ver com o direito econômico, eis que engloba, abrange todas as normas que regulamentam a situação dos empregados/operários não autônomos, em relação aos empregadores, em relação a outros empregadores e em relação à comunidade dentro da empresa (Betriebsgemeinschaft), na verdade há um relacionamento funcional entre os dois ramos do direito. Assim o empregado desenvolve na empresa sua capacitação e produção profissional colaborando destarte com a produção econômica da empresa. Por outra, os salários pagos pela empresa aos seus empregados são uma das rubricas mais importantes no cálculo do balanço de produtividade da empresa. Todos sabemos que na metodologia da recuperação empresarial o corte de salários e a total eliminação de postos de trabalho são itens sempre adotados. Como exemplo podemos citar a proposta da alta administração da Volkswagen de cortar 20000 postos de trabalho nos próximos cinco anos para assim tornar a empresa mais competitiva perante os outros concorrentes.

De outra banda, o direito laboral coletivo ou negociação coletiva imbricou-se, ultimamente, cada vez mais com o direito empresarial, o qual, como vimos, é parte do direito econômico. Tanto o Conselho Empresarial quanto o Comitê Econômico (na Alemanha), de acordo com a lei alemã - constituição da empresa (Betriebsverfassungsgesetz) são órgãos dos empregados da empresa, mas, sem dúvida nenhuma, têm 
influência direta nas funções diretivas do responsável pela empresa. Ainda mais forte se manifesta a ingerência em decorrência do instituto alemão empresarial da co-gestão, que, presente nos órgãos da empresa, às vezes até de forma paritária, modifica substancialmente normas do direito societário. O instituto da co-gestão aparece portanto na esfera do direito econômico como conjunto de normas integrantes do direito empresarial.

Em relação ao direito tributário, hoje um ramo juridico muito importante, o legislador tem utilizado normas e regulamentos tributários para alcançar e concretizar propósitos nitidamente de direito econômico. Isto, nem sempre foi assim, pois enquanto o peso dos tributos era relativamente pequeno (até a $1^{\text {a }}$ Guerra Mundial 1914-1918), o direito tributário praticamente não tinha influência no ou implicações com o direito econômico. O Tribunal Constitucional Alemão decidiu que em relação ao direito tributário "a arrecadação de impostos pode ser uma finalidade secundária" admitindo assim o propósito de direito econômico da norma/legislação tributária ( $B$ Verge 16,$147 ; 30,250,264$ e BVerge 67,256 NJW 1985,37 Investitionshilfegesetz. Consulta-se também a Abgabeordnung (AO). Regulamento dos Impostos Alemão $\S 3^{\circ}$ alínea 1 frase 1 de 1977 . É certo porém, que a lei alemã diferencia cuidadosamente a competência legislativa de direito econômico (Constituição Alemã art. $\left.74 n^{\circ} 11\right)$ da competência tributária (Constituição Alemã GG art. 105 ). Somente desta forma se admitem normas de direito econômico na roupagem do direito tributário.
Em relação ao direito penal existe o direito penal econômico, com um conjunto de normas autônomas, contidas na lei penal econômica (Wistg). O direito penal econômico stricto sensu tem como objeto principal proteger a ordem econômica estatal no seu todo. Já o direito penal econômico lato sensu, se preocupa com a criminalidade econômica e engloba todas as normas jurídicas setoriais que regulamentam a produção, montagem e distribuição de bens econômicos.

Finalmente, em relação ao direito de proteção do consumidor, não é fácil traçar limites precisos, pois assim como o direito de proteção do consumidor propriamente dito, também o direito econômico visa proteger os direitos dos consumidores. Uma possibilidade de diferenciação entre os dois ramos do direito é reconhecer que, tendo vindo o conceito da proteção do consumidor dos Estados Unidos é mais um programa jurídico-político do que uma categoria jurídico-sistemática. Assim, por exemplo, o programa de proteção contido nas normas do direito do consumidor ultrapassa os limites do direito econômico, pois regulamenta e sanciona a responsabilidade do produtor pelo produto, as condições gerais dos negócios e alguns contratos/negócios típicos para o setor consumista, como por exemplo, negócios a prazo/prestações, contratos de viagem, etc. No âmbito do direito econômico, o direito de proteção do consumidor desempenha funções no direito concorrencial, securitário e creditício. O programa do direito de proteção do consumidor, não se preocupa no 
entanto, com questões relativas ao todo da economia de um país, que lhe são estranhas. Por isso não pode também substituir o direito econômico. Pelo contrário, é em verdade uma complementação, um eventual substitutivo do direito econômico, pois se os institutos deste último (combate aos cartéis e direito concorrencial) funcionassem perfeitamente, não seria tão importante ou tão necessário.

\section{A EMPRESA (Das Unternehmen)}

O conceito básico da empresa, aparece no âmbito do direito como uma "configuração/aparição da vida": (Gebilde des Lebens) conforme Gieseke, O significado jurídico da empresa, p. 118. É uma aparição econômica-sociológica, com a qual a ordem jurídica deve se preocupar a partir de vários pontos de vista, tais como: comercial, econômico, tributário. Por isso o termo empresa quando aparece nos textos jurídicos, nem sempre tem o mesmo significado. Consequiência disso é que o significado do termo empresa deve ser construído caso a caso, a partir da inteligência das normas individuais e/ou do sentido de uma área/ setor jurídico. Esta a razão porque não é possível estabelecer um conceito unitário, válido, para todo direito econômico da empresa. No entanto, o direito econômico necessita de um conceito básico funcional de empresa. Este conceito resulta das funções globais econômicas que a empresa exercita no moderno direito econômico.
Empresa para o direito econômico é uma unidade produtiva, econômica e autônoma. Produz bens econômicos lato sensu, quer dizer mercadorias e serviços. Sua unidade é formada pelo responsável da empresa, sujeito que tem responsabilidade jurídica e econômica por toda a empresa. Este sujeito pode ser uma pessoa física, jurídica ou uma sociedade de tais pessoas. A empresa é autônoma/independente, pois o seu responsável tem fundamentalmente liberdade quanto às decisões a serem tomadas e que vão afetar a empresa. Presumivelmente tomará e deverá tomar tais decisões, antes de mais nada, no sentido de atender as expectativas e desejos de seus clientes.

Este conceito de empresa, assim estruturado e formulado, está de acordo com os dois elementos básicos do mesmo conceito de empresa, válido para a ciência econômica: produção de bens - para o mercado e para o atendimento de necessidades de terceiros, aliado à autonomia, isto é, liberdade para um planejamento autônomo relativo, econômico e de produção (autonomia econômica).

No direito empresarial Unternehmensrecht - a liberdade de empreender - Unternehmer Freiheit - é uma das características básicas. Assinala o reconhecimento desta liberdade a primazia do direito privado, no sentido da formatação da empresa de maneira privada e autônoma. Trata-se da liberdade de cada indivíduo de, sozinho ou com outros (sócios, empregados), produzir mercadorias, bens, 
coisas, ou prestar serviços, que outras pessoas físicas ou jurídicas, estão dispostas a adquirir mediante uma paga. Além da liberdade de empreender, há outros princípios importantes a considerar que inspiram o direito empresarial. Assim por exemplo: o princípio da troca - Austauschprinzip. Este princípio determina tanto o direito patrimonial civil quanto o direito econômico. Vale ainda para o direito empresarial visto como um direito organizacional que possibilita à empresa de produzir bens, coisas, serviços como uma unidade econômica autônoma com base nos contratos de troca com os seus clientes, fornecedores, bancos e também com os seus empregados. As empresas necessitam desta estrutura organizacional para garantir a sua existência, a sua sobrevivência. Surge assim mais uma característica da empresa e do direito empresarial, o princípio da continuidade e sobrevivência da empresa como unidade individual, autônoma, economicamente organizada.

Outro aspecto crucial é a característica ou princípio: da rentabilidade. Os resultados negociais positivos, os lucros devem superar os prejuízos e despesas, sob pena de colocar em risco o princípio da continuidade, da sobrevivência da empresa.

Portanto, a atividade empresarial, sem dúvida é uma atividade de risco. Como unidade individual de ação (Individuelle Aktions Einheit), a empresa tem que se afirmar no campo da livre concorrência, sob pena de sossobrar, falir. O risco desta atividade empresarial é suportado pelo ou pelos proprietários da empresa que, não raras vezes, combinam e entrelaçam o seu patrimônio pessoal e a sua capacidade técnica total ou parcialmente com os destinos da empresa. Como o(s) titular(es) da empresa, seja companhia fechada, seja aberta, garantem patrimonial e administrativamente a continuidade da empresa, é possível planejar a médio e longo prazo o seu desempenho.

O direito empresarial, parte integrante do direito econômico, é portanto, primordialmente, um direito que organiza fatores da produção, um direito organizacional - Organisationsrecht que, além de princípios do direito privado, acima perfilados, também utiliza instrumentos vários de natureza não privatística mas soberana e que por isso se diferencia do direito societário simplesmente privatístico.

Embora use normas e princípios do direito privado, o direito empresarial considera como de importância primordial os pontos de vista, os enfoques que abrangem toda economia de um país ou de uma região.

Quanto às empresas organizadas segundo determinadas fórmulas ou padrões jurídicos, o direito alemão reconhece: a) o empresário individual, (Einzelunternehmer), $b$ ) as sociedades de pessoas - (Personal Gesellschaften), c) as sociedades de capital - (Kapital Gesellschaften), d) as cooperativas (Erwerbs und Wirtschaftsgenossenschaften), e) as sociedades específicas para um determinado objeto (Gewerbespezifische Gesellschaften) e finalmente $f$ ) duas 
empresas que somente podem ser organizadas ou constituídas segundo o princípio da concessão (Konzessionsprinzip), isto é, as fundações e a associação econômica (Wirtschaftlicherverein).

As sociedades de pessoas são de três tipos: a OHG (Offene Handelsgesellschaft) $§ \S 105$ e seguintes do HGB; a sociedade em comandita KG $\S \S 161$ e seguintes do HGB e a sociedade de direito civil (Buergerlichrechtliche Gesellschaft) $\S \S 705$ e seguintes do BGB.

As sociedades de capital apresentam-se sob três formas jurídicas: a sociedade por ações; a sociedade em comandita por ações; e, a sociedade limitada $(\mathrm{GmbH})$.

As sociedades organizadas especificamente para um determinado objeto ou atividade são as associações de seguros de interesse mútuo e as sociedades de mineração: (Versicherungsverein auf Gegenseitigkeit e a Bergrechtliche Gewerkschaft).

No Direito da Comunidade Européia, há desde 01 de julho de 1989 a Associação Econômica Européia de Interesses, que pode também ser constituída como empresa na Alemanha.

\section{AS CARACTERÍSTICAS DA AUTONOMIA PRIVADA, LIBERDADE, NO DIREITO EMPRESARIAL}

É função da autonomia privada proporcionar e garantir ao empresário o máximo de liberdade para exercer seu empreendedorismo, bem como deso- nerar o estado. Suas características relevantes contribuem, significativamente, à possibilidade de sucesso do empresário. As características que podem ser arroladas, são as seguintes: 1) a liberdade/autonomia de organizar, fundar, constituir uma sociedade/ empresa. É uma característica deveras importante, pois do ponto de vista da liberdade, possibilita ao cidadão, fundamentalmente atuar como empresário. Do ponto de vista do direito econômico é também uma característica fundamental, pois assegura, legalmente, ao empreendedor o acesso ao mercado; 2 ) a característica da faculdade/liberdade de escolher o tipo, a espécie de sociedade ou associação. Trata-se aqui, com poucas restrições, da livre escolha da forma legal a ser adotada para empreender algo. Do ponto de vista do direito econômico, esta característica da autonomia privada no direito empresarial, garante uma certa capacidade de adaptação da empresa a situações futuras ainda não previsíveis; 3 ) a característica da liberdade de redigir, dentro de certos limites legais, o teor do contrato social ou os estatutos da sociedade ou associação; 4) a liberdade e autonomia de formação da vontade do empresário e dos sócios/associados, enquanto partícipes da vida da empresa; e finalmente 5) a liberdade/autonomia de dissoluções e liquidação da empresa, a outra face da moeda em relação à liberdade/autonomia de constituir, fundar, organizar empresas. 6) pode ainda ser arrolada a liberdade e autonomia do empresário para se coligar, 
vincular com outras empresas Verbindungen von Unternehmen. Tal liberdade é assegurada e garantida por lei que no entanto também a limita quando ocorrem excessos que possam ameaçar a garantia da livre concorrência. Estabelece-se então, legalmente uma limitação à liberdade organizacional do empresário do ponto de vista do direito econômico.

\section{CONCLUSÃO}

A temática deste artigo: Direito Econômico e Direito Empresarial não se esgota com o que expusemos. Muito pelo contrário. É extremamente vasto o campo da nossa matéria. Basta lembrar toda legislação de direito econômico/ empresarial que combate as limitações à livre concorrência, monopólios, cartéis, dominação de mercado, controle de grupos, consórcios, holdings, enfim concentrações de empresas, toda legislação de controle e direção de uma economia, preços, subvenções, seguros, mercado de capitais, financeiro, crédito, energia, transporte, mídia, etc.

Apenas afloramos os conceitos e temas introdutórios à disciplina e esperamos que de alguma forma, contribuirmos ao acervo de estudos já existente a respeito do direito empresarial e econômico. 